\title{
IMPLEMENTASI MANAJEMEN BALANCED SCORECARD DI PONDOK PESANTREN JAM'IYYAH ISLAMIYYAH \\ TANGERANG SELATAN
}

\author{
SAIHU \\ Dosen Institut PTIQ Jakarta \\ madesaihu@ptiq.ac.id
}

\begin{abstract}
ABSTRAK
Tulisan ini bertujuan untuk mengetahui efektivitas dalam manajemen Pondok Pesantren dengan menggunakan analisis kinerja balanced scorecard, diantaranya dengan menggunakan empat perspektif, keuangan, pelanggan, proses bisnis internal serta pembelajaran dan pertumbuhan di pondok pesantren Jam'iyyah Islamiyyah. Penelitian ini menggunakan metode pendekatan kualitatif dengan model deskriptif. Berdasarkan penelitian yang telah dilakukan diketahui bahwa Manajemen pondok pesantren Jam'iyyah Islamiyyah dengan pendekatan balanced scorecard dikategorikan baik. Karena pengukuran di empat perspektif hampir mendekati target yang diharapkan. Setelah diukur dengan pendekatan balanced scorecard kemudian dianalisis dengan indikator efektivitas menurut Danim, maka hasil yang didapat manajemen pondok pesantren Jam'iyyah Islamiyyah bisa dikatakan efektif.
\end{abstract}

Kata Kunci: Efektivitas, Manajemen Pesantren, Balanced Scorecard.

\begin{abstract}
This paper aims to determine the effectiveness in the management of Islamic boarding schools using balanced scorecard performance analysis, including using four perspectives, finance, customers, internal business processes and learning and growth in the Islamic boarding school Jam'iyyah Islamiyyah. This research uses a qualitative approach with a descriptive model. Based on research that has been done, it is known that the management of the Islamic boarding school Jam'iyyah Islamiyyah with a balanced scorecard approach is categorized as good. Because the measurement in four perspectives is close to the expected target. After being measured by the balanced scorecard approach and then analyzed with the effectiveness indicators according to Danim, the results obtained by the management of the Jam'iyyah Islamiyyah Islamic boarding school can be said to be effective.
\end{abstract}

Keywords: Effectiveness, Pesantren Management, Balanced Scorecard. 


\section{PENDAHULUAN}

Tulisan ini membahas tentang gambaran tentang efektivitas manajemen pesantren dengan pendekatan Balanced Scorecard di pondok pesantren Jam'iyyah Islamiyyah. Secara umum tulisan ini dilakukan untuk mendapatkan dan mengungkapkan hasil pengukuran efektivitas manajemen pesantren dengan pendekatan manajemen Balance Scorecard dan juga mengetahui hal-hal yang harus diperbaiki untuk meningkatkan efektivitas manajemen pondok pesantren Jam'iyyah Islamiyyah.

Lembaga pendidikan Islam dituntut untuk mendesain model-model pendidikan yang sesuai dengan kebutuhan perkembangan sekarang ini. Namun timbul pertanyaan tentang model pendidikan Islam yang bagaimana yang diharapkan dapat menghadapi dan menjawab tantangan perubahan yang terjadi dalam kehidupan masyarakat. Salah satu dari lembaga pendidikan adalah pesantren. Pesantren merupakan sistem pendidikan tertua saat ini jika dibandingkan dengan lembaga pendidikan yang pernah muncul di Indonesia dan sejak lama sudah dianggap sebagai produk budaya Indonesia yang indigenous (berkarakter khas). Lembaga pendidikan Islam ini mulai dikenal setelah masuknya Islam ke Indonesia pada abad VII, akan tetapi keberadaan dan perkembangannya baru popular sekitar abad XVI. Sejak saat itu telah banyak dijumpai lembaga yang bernama pesantren yang mengajarkan berbagai kitab Islam klasik dalam bidang fiqh, aqidah, tasawuf dan menjadi pusat penyiaran Islam. ${ }^{1}$

Menurut Jamali, Pondok Pesantren adalah lembaga pendidikan Islam tertua yang pada awal berdirinya berfungsi sebagai benteng pertahanan Islam. ${ }^{2}$ Selain itu, Pondok Pesantren juga berfungsi sebagai pusat dakwah dan pusat pengembangan masyarakat muslim di Indonesia. Sejarah juga telah membuktikan kontribusi pesantren dalam rangka turut mendirikan negara Republik Indonesia. Banyak ulama' dan santri yang gugur dalam memperjuangkan dan mempertahankan kemerdekaan.

Pengembangan manajemen pesantren merupakan salah satu solusi yang dapat digunakan untuk meningkatkan kualitas atau mutu pesantren. Manajemen mengawal dan memberikan arahan pada proses berjalannya sebuah lembaga pesantren dapat terpantau. Tak berbeda dengan lembaga pedidikan lain seperti sekolah formal, pendidikan pesantren juga membutuhkan manajemen untuk mengembangkan atau memajukan sebuah pesantren. Baik itu manajemen dari mulai kurikulum, personalia, keuangan agar pesantren lebih mampu dalam menghadapi berbagai tantangan dari waktu-waktu. ${ }^{3}$

Manajemen merupakan suatu konsep yang mengkaji keterkaitan dimensi perilaku, komponen sistem dalam kaitannya dengan perubahan dan pengembangan organisasi. Tuntutan perubahan dan pengembangan yang muncul sebagai akibat tuntutan lingkungan internal dan eksternal, membawa implikasi terhadap perubahan perilaku kelompok dan wadahnya. ${ }^{4}$ Perubahan mempunyai tujuan yang sifatnya penyesuaian diri dengan lingkungan agar tujuan organisasi sesuai dengan kebutuhan atau tuntutan masyarakat. Kunci dari perubahan di organisasi pondok pesantren adalah orang yang memimpin, yaitu bagaimana ia menjalankan masa kepemimpinannya.

Selain faktor kepemimpinan kyai atau tuan guru, perkembangan pondok pesantren tentunya juga tidak luput dari penerapan fungsi-fungsi manajemen yang lain. Manajemen adalah seperangkat aktivitas yang dirancang untuk mencapai sebuah tujuan organisasi melalui pemanfaatan sumber daya yang tersedia secara efektif dan efisien. Efektif artinya hasil tercapai sesuai dengan keinginan organisasi. Efisien artinya pekerjaan dapat diselesaikan

${ }^{1}$ Zamakhsyari Dhofier, Tradisi Pesantren: Studi Tentang Pandangan Kyai. Jakarta: LP3ES. Cet. VII. (Jakarta: LP3ES, 2011), 34.

2 Jamali, Kaum Santri Dan Tantangan Kontemporer (Bandung: Pustaka, 1999), 129.

${ }^{3}$ Nur Rohmah Hayati, "Manajemen Pesantren Dalam Menghadapi Dunia Global. Tarbawi, 1(2), $97-$ 106.," Tarbawi 1, no. 2 (2015): 97-106.

${ }^{4}$ Nanat Fatah Nasir, Integrasi Dan Konflik Dalam Adat Pertanian Masyarakat Aceh, I (Bandung: Gunung Djati Press, 1999), 39.

2 | Mumtäz Vol. 3 No. 1, Tahun 2019 
dengan menggunakan sumber daya aparatur seminimal mungkin. ${ }^{5}$ Oleh karena itu tulisan ini adalah potret efektivitas manajemen pesantren melalui pendekatan Balanced Scorecard pada pondok pesantren Jamiyyah Islamiyyah Tangerang Selatan.

\section{TINJAUAN PUSTAKA \\ a. Konsep Balanced Scorecard}

Menurut kaplan dan Norton, Balanced Scorecard (BSC) adalah suatu kerangka kerja baru untuk mengintegrasikan berbagai ukuran yang diturunkan dari strategi perusahaan. ${ }^{6} B S C$ terdiri dari dua kata, yaitu Balanced (Berimbang) dan Scorecard (kartu skor). BSC merupakan suatu alat yang mempunyai tiga elemen yaitu sistem pengukuran, sistem manajemen strategik, dan alat komunikasi. BSC menekankan pengukuran keuangan dan non keuangan, jangka pendek dan jangka panjang, internal dan eksternal berjalan seimbang. ${ }^{7} B S C$ juga memberikan suatu kerangka kerja untuk mengkomunikasikan misi dan strategi sekaligus menginformasikan kepada seluruh pekerja tentang apa yang menjadi determinan sukses saat ini dan masa mendatang. BSC dapat digunakan untuk mengartikulasi strategi bisnis, membantu menyatukan individu, dan antar departemen dalam organisasi untuk mencapai tujuan bersama.

Konsep balanced scorecard dirancang untuk diterapkan pada organisasi profit, namun tidak menutup kemungkinan untuk diterapkan pada institusi pendidikan. Lembaga pendidikan juga mempunyai empat aspek tipikal yang menjadi kajian esensial balanced scorecard untuk mengukur kinerja suatu organisasi. Hal tersebut dipertegas oleh Chang dan Chow, yang menyatakan bahwa Balanced Scorecard merupakan alat potensial untuk mendukung perubahan dan perbaikan berkelanjutan di dalam dunia pendidikan. ${ }^{8}$ Karakteristik pengukuran dengan pendekatan balanced scorecard yaitu mengukur kesatuan dari misi dan strategi yang secara ekplisit didesain untuk menyajikan dan mendorong hasil kinerja yang telah dicapai.

\section{b. Aspek-aspek yang diukur dalam Balanced Scorecard}

Balanced scorecard menerjemahkan misi dan strategi organisasi ke dalam tujuan operasional dan ukuran kinerja keuangan dan non keuangan, yang terbagi ke dalam empat perspektif: keuangan, pelanggan, proses bisnis internal, serta pembelajaran dan pertumbuhan. ${ }^{9}$ Balanced Scorecard tidak hanya sebagai alat pengukur kinerja perusahaan yang komprehensif, tetapi merupakan suatu bentuk transformasi strategik secara total kepada seluruh tingkatan dalam organisasi.

\section{Perspektif Keuangan (Financial)}

Perspektif keuangan merupakan ukuran kinerja perusahaan dengan tujuan melihat kontribusi penerapan suatu strategi perusahaan dalam memperoleh pendapatan, laba, dan nilai pasar. Ukuran keuangan biasanya diwujudkan dalam profitabilitas, pertumbuhan, dan nilai pemegang saham. Ukuran keuangan merupakan suatu ikhtisar dari konsekuensi ekonomi yang terjadi yang disebabkan oleh keputusan dan tindakan ekonomi yang telah diambil. Ukuran keuangan penting dalam memberi-kan gambaran berkenaan dengan efektivitas maupun

\footnotetext{
${ }^{5}$ Nurul Yakin, "2014. Studi Kasus Pola Manajemen Pondok Pesantren Al-Raisiyah Di Kota Mataram," Ulumuna Jurnal Studi Keislaman 18, no. 1 (2014): 201.

${ }^{6}$ and David P. Norton. Robert S. Kaplan, The Balanced Scorecard: Translating Strategy into Action (Boston: Harvard Business School Press, 1996), 71.

${ }^{7}$ Mulyadi, Balanced Scorecard: Alat Manajemen Kontemporer Untuk Pelipatganda Kinerja Keuangan (Jakarta: Salemba Empat, 2001), 3.

${ }^{8}$ Chow O.H.Chang dan C.W, "The Balanced Scorecard: A Potential Tool for Supporting Change and Continuous Improvement in Accounting Corporation,” Meditari Accountancy Research 14, no. 3 (1999): 392.

${ }^{9}$ Krismiaji, Sistem Informasi Akuntansi (Yogyakarta: AMP YKPN, 2002), 374.
} 
efisiensi melalui kebijakan yang diambil manajemen dan akhirnya bermuara dalam laporan keuangan.

Pengukuran kinerja keuangan akan menunjukkan apakah perencanaan memberikan perbaikan yang mendasar bagi keuntungan oragnisasi. Perbaikan-perbaikan ini tercermin dalam sasaran-sasaran yang secara khusus berhubungan dengan keuntungan yang terukur, pertumbuhan usaha, dan nilai pemegang saham. Ukuran kinerja finansial memberikan petunjuk apakah strategi perusahaan, implementasi dan pelaksanaannya memberikan kontribusi atau tidak kepada peningkatan laba perusahaan. Tujuan finansial biasanya berhubungan dengan profitabilitas melalui pengukuran laba operasi, return on capital employed (ROCE) atau economic value added. Tujuan finansial lainnya mungkin berupa pertumbuhan penjualan yang cepat atau terciptanya arus kas.

\section{Perspektif Pelanggan (Customer)}

Dalam pengukuran kinerja pada perspektif pelanggan dibagi menjadi dua kelompok pengukuran yaitu kelompok inti (Customer Care Measurement) dan kelompok penunjang (Customer Value Propositon). ${ }^{10}$ Kelompok pertama atau kelompok inti terdiri atas beberapa indikasi pengukuran, antara lain: a) Pangsa Pasar (Market Share). Pengukuran ini mencerminkan besarnya bagain yang dikuasai oleh perusahaan dari total keseluruhan pasar yang ada; b) Retensi Pelanggan (Customer Retention). Pengukuran ini mengukur tingkat perusahaan dalam mempertahankan jumlah pelanggan serta hubungan baik dengan pelanggan; c) Akuisisi Pelanggan (Customer Acquisition). Pengukuran ini dilakukan untuk mengetahui tingkat perusahaan dalam mendapatkan/ menarik pelanggan baru; d) Kepuasan Pelanggan (Customer Satisfaction). Pengukuran ini untuk mengukur tingkat kepuasan pelanggan terhadap produk serta pelayanan perusahaan; e) Profitabilitas Pelanggan (Customer Profitability).

Sedangkan kelompok kedua adalah merupakan kelompok yang menunjang kinerja pada kelompok inti. Kelompok penunjang menggambarkan atribut yang diberikan perusahaan kepada produk dan jasanya untuk menciptakan loyalitas dan kepuasan pelanggan, meliputi: a) Atribut produk jasa. Atribut ini meliputi atribut fungsional, harga dan mutu dari produk/jasa. Untuk atribut ini, setiap pelanggan memiliki kecenderungan tersendiri dalam memilih produk/jasa; b) Hubungan pelanggan. Pada kategori ini mencakup bagaimana perasaan pelanggan setelah membeli produk/jasa dan menerima pelayanan perusahaan. Perasaan pelanggan tersebut sangat dipengaruhi kualitas produk/jasa sertakualitas pelayanannya; c) Citra dan Reputasi. Kategori ini menggambarkan faktor-faktor tidak terwujud yang dapat membuat pelanggan tertarik pada sebuah produk /jasa. Kategori ini memungkinkan perusahaan untuk secara aktif membangun citra dan reputasi pada masyarakat.

Dalam konteks pendidikan, pelanggan adalah yang menikmati pelayanan pendidikan. Secara rinci pelanggan pendidikan terdiri dari dua macam, yaitu pelangggan internal dan pelanggan eksternal. ${ }^{11}$ Pendidikan berkualitas jika: a) Pelanggan internal (warga sekolah) berkembang secara baik dalam aspek fisik maupun psikis. Secara fisik antara lain mendapatkan imbalan finansial yang memadai sesuai dengan kinerja masing-masing. Sedangkan secara psikis, pelanggan internal memiliki kesempatan yang luas untuk terus belajar dan mengembangkan kompetensi, bakat dan kreatifitasnya; b) Pelanggan Eksternal: 1) Eksternal Primer (para siswa): menjadi pembelajar sepanjang hayat, komunikator yang baik, punya keterampilan teknologi untuk lapangan kerja dan kehidupan sehari-hari, integritas pribadi, pemecah masalah, dan penciptaan pengetahuan dan menjadi warga negara yang bertanggung jawab; 2) Eksternal Sekunder (orang tua, para pemimpin pemerintahan, dan

\footnotetext{
${ }^{10}$ Robert S. Kaplan, The Balanced Scorecard: Translating Strategy into Action, 21.

11 Nurkholis, Manajemen Berbasis Sekolah, Teori, Model, Dan Aplikasi (Jakarta: PT. Gramedia Widiasarana Indonesi, 2003), 110.

4 | Mumtäz Vol. 3 No. 1, Tahun 2019
} 
perusahaan/dunia usaha dan industri); para lulusan sekolah dapat memenuhi harapan orang tua, para pemimpin pemerintahan, dan perusahaan/dunia usaha dan industri dalam hal menjalankan tugas-tugas dan pekerjaan yang diberikan; 3) Eksternal tersier (pasar kerja dan masyarakat luas): para lulusan memiliki kompetensi dalam dunia kerja dan dalam pengembangan masyarakat sehingga mempengaruhi pada pertumbuhan ekonomi, kesejahteraan rakyat dan keadilan sosial. ${ }^{12}$

\section{3) Perspektif Proses Bisnis Internal (Internal Bussiness Process)}

Perspektif proses bisnis internal, yaitu kemampuan perusahaan untuk melakukan peningkatan secara terus-menerus melalui kegiatan proses produksi yang lebih baik, distribusi menjadi lebih cepat, cakupan hubungan masyarakat menjadi lebih luas, inovasi produk menjadi lebih cepat, serta tanggung jawab sosial ke masyarakat menjadi lebih baik. ${ }^{13}$ Dalam Proses Bisnis internal, manajer harus mampu mengidentifikasi proses bisnis internal yang penting, dimana perusahaan diharuskan melakukan yang terbaik karena proses tersebut mempunyai nilai-nilai yang diinginkan konsumen. ${ }^{14}$

Perspektif ini terdiri dari 3 komponen yaitu: a) Proses inovasi Yang mengidentifikasi kebutuhan para pelanggan hari ini dan akan datang serta mengembangkan solusi baru untuk kebutuhan pelanggan; b) Proses operasional yang mengidentifikasi sumber-sumber pemborosan dalam proses operasional serta mengembangkan solusi masalah yang terdapat dalam proses operasional demi meningkatkan efisiensi dan kualitas layanan produk/jasa; c) Proses pelayanan yang berkaitan dengan pelayanan kepada pelanggan seperti: penyelesaian masalah yang timbul pada pelanggan dalam kesempatan pertama secara cepat, melakukan tindak lanjut secara proaktif dan tepat waktu; d) Perspektif Pembelajaran dan pertumbuhan (Learning and Growth).

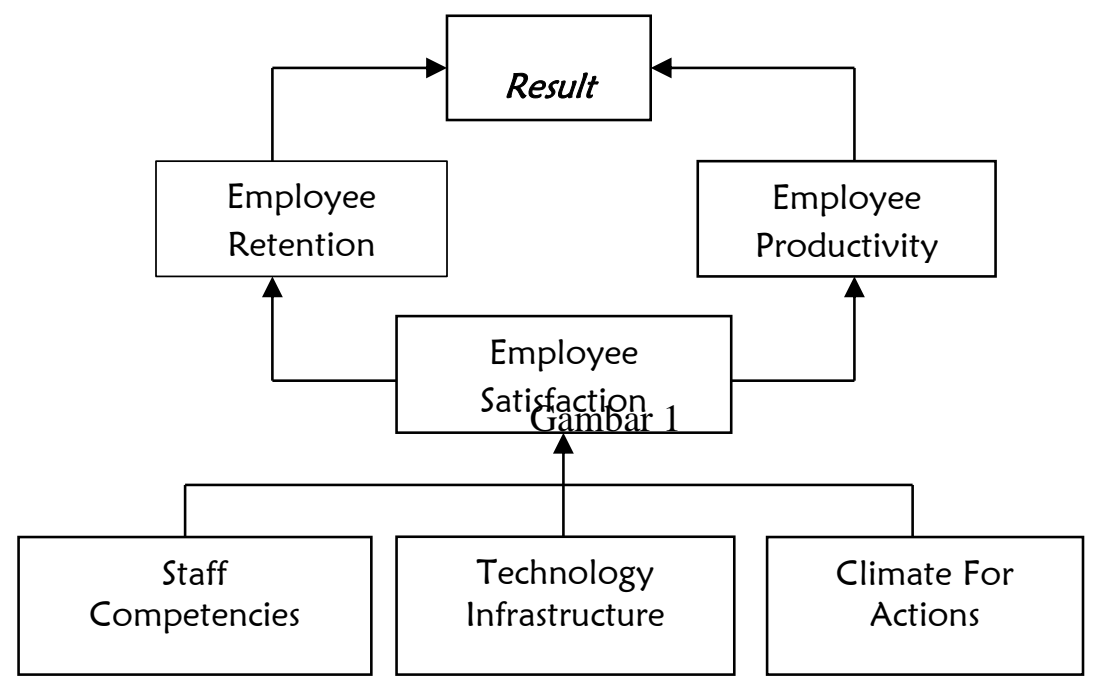

Kerangka Pengukuran Pembelajaran dan pertumbuhan

Penerapan balanced scorecard dalam organisasi publik memerlukan modifikasi, namun modifikasi tersebut tidak berarti harus berbeda dengan balanced scorecard yang diimplementasikan pada sektor bisnis. ${ }^{15}$ Hal ini didasarkan pada perbedaan tujuan antara organisasi publik dan organisasi bisnis. Organisasi publik, termasuk sekolah, merupakan

\footnotetext{
${ }^{12}$ Nurkholis, 71.

${ }^{13}$ Freddy Rangkuti, SWOT Balance Scorecard (Jakarta: Gramedia Pustaka Utama, 2012), 1.

${ }^{14}$ Irham Fahmi, Manajemen Kepemimpinan: Teori Dan Aplikasi (Bandung: ALPABETA, 2014), 192.

${ }^{15}$ Mahmudi, Manajemen Kinerja Sektor Publik (Yogyakarta: STIE YKPN, 2010), 142.
} 
organisasi yang didirikan dengan tujuan memberikan pelayanan kepada masyarakat bukan mendapatkan keuntung-an. Sementara itu, organisasi bisnis merupakan organisasi yang secara nyata berorientasi pada keuntungan. Meskipun organisasi publik bukan bertujuan mencari keuntungan, organisasi ini dapat mengukur efektivitas dan efisiensinya dalam memberikan pelayanan kepada masyarakat.

Penerapan balanced scorecard pada organisasi publik memerlukan beberapa penyesuaian atau modifikasi dengan beberapa alasan sebagai berikut: a) Fokus utama sektor publik (termasuk sekolah) adalah masyarakat dan kelompok-kelompok tertentu (interest group), sedangkan fokus utama sektor bisnis adalah pelanggan dan pemegang saham; b) Tujuan utama organisasi publik adalah bukanlah memaksimalisasi hasil finansial, tetapi keseimbangan pertanggungjawaban finansial melalui pelayanan kepada pihak-pihak yang berkepentingan (stakeholder) sesuai dengan visi dan misi organisasi publik tersebut; c) Mendefinisikan ukuran dan target dalam perspektif pelanggan dan stakeholder membutuhkan pandangan dan kepedulian yang tinggi, sebagai konsekuensi dari peran kepengurusan organisasi publik, dan membutuhkan definisi yang jelas serta hasil strategis yang diinginkan. Misalnya, penentuan siapa yang menjadi stakeholders, pemeliharaan sumber daya, tujuan strategis, ukuran kinerja, target kinerja, dan program tindakan membutuhkan deinisi yang jelas. ${ }^{16}$ Indikator penilaian kinerja perspektif Pertumbuhan dan pembelajaran yang dapat digunakan adalah: a) Peningkatan kepuasan pegawai; b) Peningkatan kompetensi pegawai; c) Pembinaan akhlaq.

Dalam Balanced Scorecard, keempat persektif tersebut menjadi satu kesatuan yang tidak dapat dipisahkan. Keempat perspektif tersebut juga merupakan indikator pengukuran kinerja yang saling melengkapi dan saling memiliki hubungan sebab akibat. ${ }^{17}$

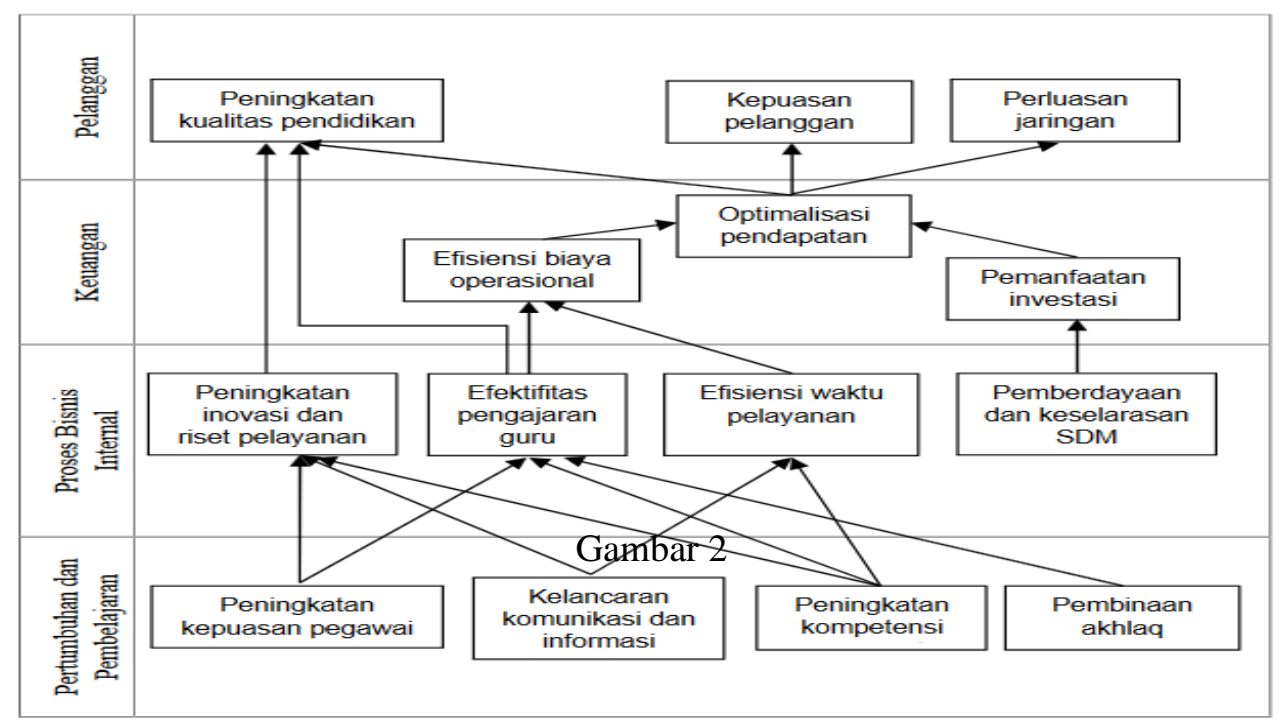

Strategy Map

\section{METODE PENELITIAN}

Tulisan ini menggunakan metode kualitatif. Menurut Sugiyono, metode penelitian kualitatif adalah metode penelitian yang digunakan untuk meneliti pada kondisi objek alamiah dimana peneliti adalah sebagai instrument kunci, teknik pengumpulan data dilakukan secara

\footnotetext{
${ }^{16}$ Dadang Dally, Balanced ScoreCard:Suatu Pendekatan Dalam Implementasi Manajemen Berbasis Sekolah (Bandung: PT Remaja Rosdakarya., 2010), 79.

${ }^{17}$ Sudarwan Danim, 2012. Motivasi Kepemimpinan Dan Efektivitas Kelompok (Jakarta: Rineka Cipta, 2012), 199-120.

6 | Mumtäz Vol. 3 No. 1, Tahun 2019
} 
gabungan, analisis data bersifat induktif, dan hasil penelitian kualitatif lebih menekankan makna dari pada generalisasinya. ${ }^{18}$ Sedangkan jenis penelitian yang dipakai oleh peneliti adalah jenis deskriptif. Penelitian deskriptif kualitatif ditujukan untuk mendeskripsikan dan menggambarkan fenomena-fenomena yang ada, baik bersifat alamiah maupun rekayasa manusia, yang lebih memperhatikan mengenai karakteristik, kualitas, keterkaitan antar kegiatan. ${ }^{19}$

Selain itu, Penelitian deskriptif tidak memberikan perlakuan, manipulasi atau pengubahan pada variabel-variabel yang diteliti, melainkan menggambarkan suatu kondisi yang apa adanya. Satu-satunya perlakuan yang diberikan hanyalah penelitian itu sendiri, yang dilakukan melalui observasi dan wawancara. Pendekatan ini digunakan untuk memperoleh gambaran tentang kinerja Pondok Pesantren Jam'iyyah Islamiyyah dalam perspektif keuangan, perspektif pelanggan, perspektif proses bisnis internal, perspektif pembelajaran dan pertumbuhan.

\section{HASIL DAN PEMBAHASAN}

\section{Sasaran Strategi dengan Balanced Scorecard}

Pengukuran Balanced Scorecard menurut Robert S. Kaplan dan David P. Norton, merupakan suatu metode penilaian yang mencakup empat perspektif untuk mengukur kinerja perusahaan, yaitu perspektif keuangan, perspektif pelanggan, perspektif proses bisnis internal dan perspektif pembelajaran dan pertumbuhan.

\section{a) Perspektif keuangan}

Sasaran strategi dalam perspektif keuangan yaitu dengan menggunakan beebrapa rumus perhitungan rasio keuangan yaitu meliputi mengukur rasio peningkatan efisiensi aktivitas program dan non program, serta peningkatan dukungan publik.

\section{b) Perspektif pelanggan}

Santri yang yang bermukim di pondok pesantren adalah milik yayasan. Sasaran strategi pada perspektif pelanggan yaitu peningkatan kepuasan santri dan peningkatan jumlah santri. Yayasan menempatkan perspektif pelanggan memiliki tingkat kepentingan paling tinggi karena menurut yayasan para pelanggan merupakan amanah yang harus dijaga dan diutamakan.

\section{c) Perspektif proses bisnis internal}

Sasaran strategi dalam perspektif proses bisnis internal yaitu meningkatkan inovasi dan meningkatkan proses pelayanan. Hal ini digunakan untuk meningkatkan mutu pelayanan yayasan.

\section{d) Perspektif pertumbuhan dan pembelajaran}

Sasaran strategi dalam perspektif pertumbuhan dan pembelajaran yaitu peningkatan kualitas dan kompetensi (mutu SDM) dan peningkatan kepuasan pelanggan

\section{Pembobotan Balanced Scorecard}

Tujuan dari proses pembobotan yaitu untuk mengetahui tingkatan yang dijadikan prioritas diantara empat perspektif Balanced Scorecard. Berdasarkan wawancara dengan KH. Husnul 'Aqib (Pengasuh Pondok Pesantren Jam'iyyah Islamiyyah) tanggal 20 April 2019, untuk mengetahui pembobotan yang ditentukan pesantren atas masing-masing perspektif dalam balanced scorecard, adalah sebagai berikut:

${ }^{18}$ Sugiyono, Metode Penelitian Pendidikan: Pendekatan Kuantitatif, Kualitatif, Dan $R \&$ D, 11 th ed. (Bandung: ALPABETA, 2010), 9.

${ }^{19}$ Nana Syaodih Sukmadinata, Metode Penelitian Pendidikan (Bandung: PT. Rosdakarya, 2007), 73. 
a) Perspektif keuangan: bobot yang diberikan yaitu $20 \%$ yang mana terdiri dari efisiensi aktivitas program dan non program masing-masing memiliki bobot $7 \%$ dengan target realisasinya sebesar $75 \%$ sedangkan untuk dukungan publik memiliki bobot $6 \%$ dengan target dari pencapaiannya adalah sebesar $75 \%$.

b) Perspektif pelanggan: beri bobot yang paling besar yaitu $40 \%$ dan untuk sasaran strategi peningkatan jumlah pelanggan sebesar $10 \%$ dengan target realisasi sebesar $75 \%$ dan peningkatan kepuasan pelanggan bobotnya 30\% dengan target realisasi $100 \%$ karena menurut saya kepuasan pelanggan merupakan hal yang penting yang harus diperhatikan oleh pihak yayasan.

c) Perspektif proses bisnis internal berbobot $20 \%$ yang dibagi untuk peningkatan inovasi $10 \%$ dengan target realisasi $85 \%$ sedangkan peningkatan proses pelayanan bobot $10 \%$ target realisasi $90 \%$

d) Perspektif pembelajaran dan pertumbuhan memiliki bobot $20 \%$ ntruk strategi mutu SDM memiliki bobot $10 \%$ dengan target $75 \%$, dan yang terakhir peningkatan kepuasan pegawai memiliki bobot $10 \%$ dengan target realisasi $100 \%$.

Berikut merupakan pembobotan dari keempat perspektif Balanced Scorecard yang disajikan dalam bentuk tabel:

Tabel. 1

Pembobotan Masing-Masing Perspektif Balanced Scorecard

\begin{tabular}{|c|c|c|c|}
\hline Perspektif & Bobot & Sasaran Strategi & Bobot \\
\hline \multirow{3}{*}{ Perspektif Keuangan } & \multirow{3}{*}{$20 \%$} & Efisiensi Aktivitas non Program & $7 \%$ \\
\hline & & Dukungan Publik & $6 \%$ \\
\hline & & Efisiensi Program & $7 \%$ \\
\hline \multirow{2}{*}{ Perspektif Pelanggan } & \multirow{2}{*}{$40 \%$} & Peningkatan Jumlah Pelanggan & $10 \%$ \\
\hline & & Peningkatan Kepuasan Pelanggan & $30 \%$ \\
\hline \multirow{2}{*}{ Perspektif Proses Bisnis Internal } & \multirow{2}{*}{$20 \%$} & Peningkatan Inovasi & $10 \%$ \\
\hline & & Peningkatan Proses Layanan & $10 \%$ \\
\hline \multirow{2}{*}{$\begin{array}{l}\text { Perspektif Pembelajaran dan } \\
\text { pertumbuhan }\end{array}$} & \multirow{2}{*}{$20 \%$} & $\begin{array}{l}\text { Peningkatan kualitas dan } \\
\text { Kompetensi }\end{array}$ & $10 \%$ \\
\hline & & Peningkatan Kepuasan Pelanggan & $10 \%$ \\
\hline
\end{tabular}

\section{Penentuan Key Performance Indicator's (KPI)}

Pada hakikatnya indikator merupakan suatu alat ukur yang digunakan untuk menjelaskan dan memahamkan mengenai hasil dari suatu aktivitas kegiatan. Penentuan Key Performance Indicator's (KPI) merupakan bagian yang sangat penting dalam merancang 
sistem pengukuran kinerja. KPI digunakan untuk mengukur tingkat pertumbuhan usaha dan posisi keunggulan bersaing. ${ }^{20}$

Berdasarkan dari hasil pembobotan dapat dilihat bahwa perspektif keuangan yang menjadi indikator kunci yaitu peningkatan pendapatan dari publik, peningkatan efisiensi aktivitas program dan non program, dan peningkatan efektivitas investasi. Dalam perspektif pelanggan memiliki dua sasaran strategi yaitu peningkatan jumlah pelanggan dan peningkatan kepuasan pelanggan, dari kedua strategi tersebut dapat diperoleh indikator kunci yaitu meningkatkan jumlah pelanggan dan meningkatkan kepuasan pelanggan terhadap layanan yang diberikan. Perspektif Proses Bisnis Internal memiliki indikator kunci yaitu pengembangan inovasi dan layanan produk dan jasa serta peningkatan pelayanan kepada pelanggan. Dan yang terakhir Perspektif Pembelajaran dan pertumbuhan memiliki indikator kunci yaitu prosentase keikutsertaan pegawai dalam pelatihan dan seminar serta meningkatkan kepuasan kerja pegawai.

Berikut ini disajikan Key Performance Indicator's (KPI) untuk memudahkan peneliti menentukan sasaran strategi dari tiap masing-masing perspektif Balanced Scorecard di pondok pesantren Jam'iyyah Islamiyyah.

Tabel. 2

Key Performance Indicator's (KPI)

Masing-Masing Perspektif Balanced Scorecard

\begin{tabular}{|c|c|c|}
\hline Perspektif & Sasaran Strategi & KPI \\
\hline \multirow{3}{*}{ Keuangan } & $\begin{array}{l}\text { Efisiensi Aktivitas non } \\
\text { program }\end{array}$ & Efisiensi Aktivitas non program \\
\hline & Dukungan publik & Peningkatan pendapatan dari publik \\
\hline & Efisiensi program & Efisiensi program \\
\hline \multirow{3}{*}{ Pelanggan } & $\begin{array}{l}\text { Peningkatan Jumlah } \\
\text { Pelanggan }\end{array}$ & Peningkatan Jumlah Pelanggan \\
\hline & \multirow{2}{*}{$\begin{array}{l}\text { Peninggkatan kepuasan } \\
\text { Pelanggan }\end{array}$} & $\begin{array}{c}\text { Kepuasan Pelanggan terhadap layanan } \\
\text { yang diberikan }\end{array}$ \\
\hline & & Pemenuhan sarana dan prasarana \\
\hline \multirow{2}{*}{$\begin{array}{l}\text { Proses Bisnis } \\
\text { Internal }\end{array}$} & Peningkatan Inovasi & $\begin{array}{l}\text { Pengembangan inovasi layanan produk } \\
\text { dan jasa lembaga }\end{array}$ \\
\hline & $\begin{array}{l}\text { Peningkatan Proses } \\
\text { layanan }\end{array}$ & $\begin{array}{l}\text { Meningkatkan layanan kepada } \\
\text { pelanggan }\end{array}$ \\
\hline \multirow{2}{*}{$\begin{array}{l}\text { Pembelajaran dan } \\
\text { pertumbuhan }\end{array}$} & $\begin{array}{l}\text { Peningkatan kualitas dan } \\
\text { kompetensi }\end{array}$ & $\begin{array}{l}\text { Prosentase keikutsertaan pegawai dalam } \\
\text { pelatihan dan seminar }\end{array}$ \\
\hline & $\begin{array}{l}\text { Peningkatan kepuasan } \\
\text { pegawai }\end{array}$ & Peningkatan kepuasan pegawai \\
\hline
\end{tabular}

20 Mulyadi, Balanced Scorecard: Alat Manajemen Kontemporer Untuk Pelipatganda Kinerja Keuangan, 34. 


\section{Pengukuran Pondok Pesantren dengan Balanced Scorecard a) Perspektif Keuangan (Finance)}

Sesuai hasil wawancara dengan Bisri Mustofa (Kabag TU dan Keuangan), meyatakan bahwa sistem manajemen keuangan pondok pesantren Jam'iyyah Islamiyyah menggunakan sistem satu pintu, yakni segala jenis pembayaran baik SPP, Pembangunan dan jenis biaya penunjang lainnya dibayarkan melalui loket pembayaran yang berada di diantara gedung MTs dan MA. Sehingga memudahkan kepala Bagian Keuangan dan Tata Usaha beserta staffnya mengelola pembayaran yang masuk serta pemasukan lainnya untuk dipergunakan sebagaimana mestinya. Uang Pendaftaran yang sebesar 4-5 Jutaan pertahun ditambah dengan pembayaran SPP untuk santri sebesar 700/ bulan sangat memungkinkan bagi pihak pesantren mengelola dengan baik proses perputaran keuangan pihak yayasan. Sehingga semua kebutuhan maupun sarana-prasarana bisa dikembangkan.

Tabel. 3

Pemasukan Keuangan Pertahun

\begin{tabular}{|c|c|c|c|}
\hline \multirow{2}{*}{ Laporan Keuangan } & Tahun 2015 & Tahun 2016 & Tahun 2017 \\
\cline { 2 - 4 } & Rp. 4,5 & Rp. 4,7 & Rp. 5,1 \\
\hline Pendaftaran & 666.000 .000 & 606.300 .000 & 637.500 .000 \\
\hline SPP & 302.400 .000 & 303.800 .000 & 308.000 .000 \\
\hline Total & 968.400 .000 & 910.100 .000 & 945.500 .000 \\
\hline
\end{tabular}

Pihak Pondok Pesantren Jam'iyyah Islamiyyah yang diakomodir oleh ka Bagian Keuangan dan Tata Usaha telah bekerja sama dengan BANK BRI untuk memberikan uang gaji para karyawan dengan cara mentransfernya dan juga menerima pembayaran dengan sistem transfer dengan cara memberikan bukti transfer. Pengukuran perspektif keuangan dilakukan dengan menghitung rasio-rasio dihitung mulai dari tahun 2015 hingga tahun 2017.

Tabel. 4

Laporan Keuangan Pondok Pesantren Jam'iyyah Islamiyyah Periode 2015-2017

\begin{tabular}{|c|c|c|c|}
\hline \multirow{2}{*}{ Laporan Keuangan } & Tahun 2015 & Tahun 2016 & Tahun 2017 \\
\cline { 2 - 4 } & Rp. & Rp. & Rp. \\
\hline Biaya Non Program & 65.490 .000 & 73.710 .000 & 89.310 .000 \\
\hline Biaya Program & 13.880 .000 & 14.840 .000 & 19.050 .000 \\
\hline Total Pendapatan & 172.800 .000 & 173.600 .000 & 220.000 .000 \\
\hline Total Biaya & 79.370 .000 & 88.550 .000 & 108.360 .000 \\
\hline Total Kontribusi & 62.400 .000 & 64.000 .000 & 87.800 .000 \\
\hline
\end{tabular}

Macam-macam rasio keuangan yang digunakan dalam mengukur kinerja perspektif keuangan Pondok Pesantren Jam'iyyah Islamiyyah adalah sebagai berikut:

\section{Rasio efisiensi aktivitas non program}

Dalam perhitungan rasio efisiensi aktivitas non program digunakan satu macam rasio seperti yang ditunjukkan dalam tabel dibawah ini, yaitu: 
Tabel. 5

Rasio Efisiensi Aktivitas Non Program

Pondok Pesantren Jam'iyyah Islamiyyah periode 2015-2017

\begin{tabular}{|c|c|c|c|}
\hline Rasio Efisiensi Aktivitas Non Program & $\mathbf{2 0 1 5}$ & $\mathbf{2 0 1 6}$ & $\mathbf{2 0 1 7}$ \\
\hline Total pendapatan/total biaya non program & 2.63 & 2.35 & 2.46 \\
\hline
\end{tabular}

Rasio efisiensi program yang merupakan komponen dari total pendapatan dibagi dengan total biaya non program. Dari hasil perhitungan rasio tersebut selama 3 tahun yaitu tahun 2015, 2016 dan 2017 mengalami gelombang naik turun yaitu pada tahun 2016 lebih kecil dari tahun 2015 dan 2017. Berdasarkan hal tersebut, maka dapat dikatakan bahwa rasio efisiensi aktivitas non program Pondok Pesantren Jam'iyyah Islamiyyah kurang efisien karena terjadi gelombang naik turun yang disebabkan oleh pengeluaran yang terjadi dalam usaha pencarian dana lebih besar jika dibandingkan dengan pendapatan yang diperolehnya.

\section{Rasio dukungan publik}

Rasio ini terdapat rasio yang digunakan yaitu disajikan dalam tabel berikut:

Tabel. 6

Rasio Dukungan Publik

Pondok Pesantren Jam'iyyah Islamiyyah periode 2015-2017

\begin{tabular}{|c|c|c|c|}
\hline Rasio Dukungan Publik & $\mathbf{2 0 1 5}$ & $\mathbf{2 0 1 6}$ & $\mathbf{2 0 1 7}$ \\
\hline Total kontribusi/total pendapatan & 0.361 & 0.368 & 0.399 \\
\hline
\end{tabular}

Berdasarkan tabel di atas tampak bahwa dalam 3 tahun terakhir yaitu tahun 2015, 2016 dan 2017 rasio dukungan publik mengalami peningkatan. Hal ini dapat diartikan bahwa dalam menghimpun dana dari donatur Pesantren mampu melakukannya dengan baik sehingga tiap tahunnya dapat bertambah. Berdasarkan hal tersebut bisa dikatakan bahwa rasio dukungan publik Pesantren sebagian besar berasal dari kontribusi, karena organisasi sangat bergantung pada sumbangan donatur untuk mendanai kegiatan operasionalnya. Sehingga sangat rentan terhadap fluktuasi dana sumbangan yang terbentuk.

\section{Rasio efisiensi Program}

Rasio ini memiliki 1 rumus rasio yang digambarkan dalam tabel dibawah ini yaitu:

Tabel. 6

Rasio efisiensi program

Pondok Pesantren Jam'iyyah Islamiyyah periode 2015-2017

\begin{tabular}{|c|c|c|c|}
\hline Rasio Efisiensi program & $\mathbf{2 0 1 5}$ & $\mathbf{2 0 1 6}$ & $\mathbf{2 0 1 7}$ \\
\hline Biaya Program/total biaya & 0.174 & 0.167 & 0.175 \\
\hline
\end{tabular}

Tabel diatas memperlihatkan bahwa rasio efisiensi program Pondok Pesantren Jam'iyyah Islamiyyah mengalami naik turun yaitu pada tahun 2015 sebesar 0,174 dan pada tahun 2016 mengalami kenaikan menjadi 0,167 sedangkan pada tahun 2017 mengalami penurunan lagi yaitu menjadi 0,175 . Berdasarkan hal tersebut dapat dikatakan bahwa kenaikan dan penurunan tersebut dikarenakan ketidak stabilan biaya program jika 
dibandingkan dengan total biaya. Sehingga hal tersebut dapat diartikan bahwa aktivitas yayasan dalam menjalankan program-programnya masih kurang efisien dikarenakan masih belum stabil.

Dari perhitungan ketiga rasio diatas, menggambarkan bahwa kondisi keuangan yaysan masih kurang efisien karena masih hasil perhitungan rasio dari tahun ke tahun masih berfluktuasi, hal ini sesuai dengan hasil wawancara penulis dengan kepala bagian keuangan dan tata usaha tentang faktor penghambat kinerja yayasan yaitu yang terjadi pada tanggal 21 April 2019 yaitu: "Faktor yang menjadi penghambat dalam peningkatan kinerja yayasan kadangkala bersumber dari sisi keuangan, dimana kadangkala sumber pendanaan yayasan menipis karena harus ada pendanaan yang harus ditutupi, namun hal tersebut tidak menjadi masalah besar yang dapat mengganggu kinerja yayasan karena masih terganti di bulan / tahun berikutnya dan bisa teratasi dengan baik".

Tabel. 7

Pencapaian Sasaran Strategi Perspektif Keuangan

\begin{tabular}{|c|c|c|c|c|c|c|}
\hline \multicolumn{7}{|c|}{ Perspektif Keuangan (bobot 20\%) } \\
\hline No & Sasaran Strategi & Ukuran Hasil & Bobot & Target & Realisasi & skor \\
\hline 1 & $\begin{array}{c}\text { Efisiensi aktivitas } \\
\text { non program }\end{array}$ & $\begin{array}{c}\text { Efisiensi aktivitas } \\
\text { non program }\end{array}$ & $7 \%$ & $75 \%$ & $50 \%$ & 5 \\
\hline 2 & Dukungan publik & $\begin{array}{c}\text { Peningkatan } \\
\text { pendapatan dari } \\
\text { publik }\end{array}$ & $6 \%$ & $75 \%$ & $75 \%$ & 6 \\
\hline 3 & Efisiensi program & Efisiensi program & $7 \%$ & $75 \%$ & $60 \%$ & 6 \\
\hline
\end{tabular}

\section{b) Perspektif Pelanggan}

Penilaian kinerja perspektif pelanggan Pondok Pesantren Jam'iyyah Islamiyyah bertujuan untuk mengetahui bagaimana pelanggan menilai Pesantren dalam menyediakan jasa pelayanan apakah sudah sesuai dengan keinginan pelanggan. Perspektif ini merupakan perspektif yang paling menjadi perhatian dalam pengukuran kinerja dengan menggunakan Balanced Scorecard. Perspektif pelanggan dapat diukur menggunakan: Akuisisi pelanggan dan kepuasan pelanggan. Sebelum menganalisis kinerja dengan perspektif pelanggan, terlebih dahulu disajikan data pelanggan yayasan selama 3 tahun yaitu tahun 2015-2017:

Tabel. 8

Data Pelanggan Pondok Pesantren Jam'iyyah Islamiyyah

\begin{tabular}{|c|c|c|c|}
\hline Tahun & Pelanggan Lama & Pelanggan Baru & Total \\
\hline 2015 & 284 & 148 & 432 \\
\hline 2016 & 305 & 129 & 434 \\
\hline 2017 & 315 & 125 & 440 \\
\hline
\end{tabular}

\section{1) Akuisisi Pelanggan}

Akuisisi pelanggan merupakan kemampuan lembaga dalam memperoleh pelanggan baru. Pengukuran kinerja dalam perspektif ini yaitu dengan membandingkan jumlah 
pelanggan baru dari tahun ke tahun. Jika terdapat peningkatan jumlah pelanggan maka perusahaan dinilai mampu memperoleh pelanggan baru. Berikut tabel yang menyajikan perhitungan akuisisi pelanggan Pondok Pesantren Jam'iyyah Islamiyyah tahun 2015, 2016 dan 2017 yaitu:

Tabel. 9

Akuisisi Pelanggan Periode 2015-2017

\begin{tabular}{|l|c|c|c|}
\hline & 2015 & 2016 & 2017 \\
\hline Akuisisi Pelanggan & 148 & 129 & 125 \\
\hline Total pelanggan & 432 & 434 & 440 \\
\hline$\%$ Akuisisi Pelanggan & $2,9 \%$ & $3,3 \%$ & $3,5 \%$ \\
\hline
\end{tabular}

Dari tabel diatas, terlihat bahwa selama 3 tahun terakhir akuisisi pelanggan pada Pondok Pesantren Jam'Iyyah Islamiyyah mengalami penurunan dari tahun ke tahun. Akan tetapi, persentase akuisisi pelanggan dari jumlah total pelanggan dibagi akuisisi pelanggan maka persentase total akuisisi pada tahun 2015 mengalami peningkatan sebesar 2,9\% menjadi $3,3 \%$, sedangkan pada tahun 2016 juga mengalami peningkatan yaitu sebesar 3,3\% menjadi $3,5 \%$. Hal tersebut menunjukkan bahwa Pondok Jam'iyyah Islamiyyah dianggap sangat baik dalam memperoleh pelanggan baru dan mempertahankan pelanggan lama. Menurut $\mathrm{KH}$. Husnul Aqib, bahwa penurunan jumlah pelanggan baru bukan karena faktor minat masyarakat akan tetapi dikarenakan jumlah kuota santri yang bisa masuk atau tinggal dipesantren terbatas. Kami sedang berusaha sampai saat ini membangun asrama santri dan memberikan kualitas layanan yang ditawarkan pesantren dengan baik sehingga meningkatnya minat yang besar bagi masyarakat untuk menuntut ilmu di Pesantren ini (wawancara dengan KH. Husnul 'Aqib, tanggal 12 April 2019).

\section{2) Kepuasan Pelanggan}

Beberapa variabel yang perlu diperhatikan untuk mengukur kepuasan pelanggan dalam bentuk kuisioner kepuasan pelanggan. Kuesioner tersebut terdiri dari 10 item pertanyaan bagi kuisioner pelanggan. Data dari kuesioner tersebut bersifat kualitatif dan kemudian diubah menjadi kuantitatif dengan memberikan skor pada masing-masing pilihan jawaban dengan skala likert, meliputi: a) Sangat Puas (SP) diberi skor 5; b) Puas (P) diberi skor 4; c) Netral (N) diberi skor 3; d) Tidak Puas (TP) diberi skor 2; e) Sangat Tidak Puas (STP) diberi skor $1 .^{21}$ Jumlah kuisioner yang dibagikan kepada pelanggan adalah sebanyak 100 kuisioner dibagikan kepada 50 santri putra dan 50 santri putri dengan total pertanyaan dalam kuesioner adalah sebanyak 10 pertanyaan.

Berikut standar minimal yang ditetapkan untuk melihat tingkat kepuasan pelanggan adalah didasarkan pada skala yang digunakan untuk pengolahan data berikut:

$$
\begin{array}{ll}
\text { Interval } & =(\mathrm{IK} \text { maks-IK min }): 5 \\
\text { Ik maks } & =\mathrm{R} \times \mathrm{PP} \times \mathrm{EX} \text { maks } \\
& =100 \times 10 \times 5 \\
& =5000 \\
\text { IK min } & =\mathrm{R} \times \mathrm{PP} \times \mathrm{EX} \min \\
& =100 \times 10 \times 1 \\
& =1000 \\
\text { Interval } & =(5000-1000): 5
\end{array}
$$

\footnotetext{
${ }^{21}$ Sugiyono, Metode Penelitian Pendidikan: Pendekatan Kuantitatif, Kualitatif, Dan R \& D, 93.
} 
Dimana :

$$
=800
$$

$$
\begin{array}{ll}
\text { PP } & =\text { banyak pertanyaan } \\
\mathrm{R} & =\text { jumlah responden } \\
\text { EX maks } & \text { = skor maksimal yang diberikan } \\
\text { EX min } & =\text { skor minimal yang diberikan } \\
\text { 1. } & 1000-1800=\text { dikategorikan sangat tidak puas } \\
\text { 2. } & 1801-2601=\text { dikategorikan tidak puas } \\
\text { 3. } & 2602-3202=\text { dikategorikan netral } \\
\text { 4. } & 3403-4203=\text { dikategorikan puas } \\
\text { 5. } & 4204-5004=\text { dikategorikan sangat puas }
\end{array}
$$

Berdasarkan interval data yang dipaparkan, maka lima kategori diatas telah diperoleh. kategori diatas nanti digunakan sebagai perhitungan atas kuisioner sehingga diketahui berada pada posisi manakah tingkat kepuasan pelanggan tersebut. Indeks kepuasan pelanggan yang diperoleh adalah 3.941, sehingga dapat dikategorikan pelanggan tersebut puas. Hal ini menunjukkan indeks kepuasan yang baik yaitu dengan pelanggan merasa puas atau berada pada interval antara 3403-4203.

Tabel. 10

Jawaban Responden Pelanggan

\begin{tabular}{|c|c|c|c|c|c|c|c|c|c|c|}
\hline \multirow{2}{*}{$\begin{array}{c}\text { Item } \\
\text { pertanyaan }\end{array}$} & \multicolumn{10}{|c|}{ JAWABAN } \\
\cline { 2 - 13 } & \multicolumn{2}{|c|}{ STP } & \multicolumn{2}{|c|}{ TP } & \multicolumn{2}{|c|}{ N } & \multicolumn{2}{c|}{ P } & \multicolumn{2}{c|}{ SP } \\
\cline { 2 - 13 } & $\mathrm{F}$ & $\%$ & $\mathrm{~F}$ & $\%$ & $\mathrm{~F}$ & $\%$ & $\mathrm{~F}$ & $\%$ & $\mathrm{~F}$ & $\%$ \\
\hline 1 & 0 & 0 & 0 & 0 & 33 & 33 & 65 & 65 & 2 & 2 \\
\hline 2 & 0 & 0 & 0 & 0 & 22 & 22 & 65 & 65 & 13 & 13 \\
\hline 3 & 0 & 0 & 0 & 0 & 26 & 26 & 64 & 64 & 10 & 10 \\
\hline 4 & 0 & 0 & 0 & 0 & 24 & 24 & 75 & 75 & 1 & 1 \\
\hline 5 & 0 & 0 & 0 & 0 & 14 & 14 & 82 & 82 & 4 & 4 \\
\hline 6 & 0 & 0 & 0 & 0 & 12 & 12 & 67 & 67 & 21 & 21 \\
\hline 7 & 0 & 0 & 0 & 0 & 17 & 17 & 64 & 64 & 19 & 19 \\
\hline 8 & 0 & 0 & 0 & 0 & 16 & 16 & 74 & 74 & 10 & 10 \\
\hline 9 & 0 & 0 & 0 & 0 & 5 & 5 & 65 & 65 & 30 & 30 \\
\hline 10 & 0 & 0 & 0 & 0 & 7 & 7 & 86 & 86 & 7 & 7 \\
\hline
\end{tabular}

Dari tabel diatas dapat dijelaskan bahwa di Pondok Pesantren Jamiyyah Islamiyyah:

1. Sebanyak $65 \%$ responden menyatakan puas dengan produk dan jasa.

2. Sebanyak $65 \%$ responden menyatakan puas dengan kualitas pelayanan.

3. Sebanyak $64 \%$ responden menyatakan puas dengan kemudahandalam mendapatkan pelayanan.

4. Sebanyak $75 \%$ responden menyatakan puas dengan penanganan keluhan pelanggan.

5. Sebanyak $82 \%$ responden menyatakan puas.

6. Sebanyak $67 \%$ responden menyatakan puas dengan kenyamanan lingkungan.

7. Sebanyak $64 \%$ responden menyatakan puas dengan sarana dan prasarana.

8. Sebanyak $74 \%$ responden menyatakan puas dengan akses yang disediakan.

9. Sebanyak $65 \%$ responden menyatakan puas dengan biaya yang dikeluarkan untuk menikmati layanan yang disediakan. 
10. Sebanyak $86 \%$ responden menyatakan puas dengan melakukan hubungan dengan lembaga.

Tabel. 11

Pencapaian Sasaran Strategi Perspektif Pelanggan

\begin{tabular}{|c|c|c|c|c|c|c|}
\hline \multicolumn{7}{|c|}{ Perspektif pelanggan (bobot 40\%) } \\
\hline No & Sasaran Strategi & Ukuran Hasil & Bobot & Target & Realisasi & skor \\
\hline 1 & $\begin{array}{c}\text { Peningkatan jumlah } \\
\text { pelanggan }\end{array}$ & $\begin{array}{c}\text { Meningkatkan } \\
\text { jumlah pelanggan }\end{array}$ & $10 \%$ & $75 \%$ & $47 \%$ & 6 \\
\hline & $\begin{array}{c}\text { Peningkatan kepuasan } \\
\text { pelanggan }\end{array}$ & $\begin{array}{c}\text { Peningkatan } \\
\text { indeks kepuasan } \\
\text { pelanggan }\end{array}$ & $30 \%$ & $100 \%$ & $95 \%$ & 28 \\
\hline
\end{tabular}

\section{c) Perspektif Proses Bisnis Internal}

Pengukuran kinerja perspektif proses internal dapat dilakukan dengan melihat aspek berikut yaitu peningkatan inovasi dan pemberdayaan dan keselarasan SDM.

1. Peningkatan inovasi

Untuk mengukur tingkat inovasi yang dilakukan yaitu dengan melihat inovasi yang direalisasikan oleh yayasan dibandingkan dengan inovasi yang ditargetkan. Inovasi yang direncanakan dan direalisasikan dari tahun 2015-2017 secara garis besar sebagai berikut adalah sebagai berikut:

Tabel. 12

Realisasi Inovasi Pondok Pesantren Jam'iyyah Islamiyyah

\begin{tabular}{|c|l|c|}
\hline No & \multicolumn{1}{|c|}{ Inovasi } & Keterangan \\
\hline 1 & Membuka kelas bimbingan khusus qiro'atul kutub & Terealisasi \\
\hline 2 & Membuka madrasah tahfidzul Qur'an & Terealisasi \\
\hline 3 & Mengadakan reuni Akbar & Terealisasi \\
\hline 4 & $\begin{array}{l}\text { Membeli lahan untuk membuka unit usaha baru milik } \\
\text { yayasan }\end{array}$ & $\begin{array}{c}\text { Belum } \\
\text { Terealisasi }\end{array}$ \\
\hline 5 & Menambah asrama baru untuk putri & Terealisasi \\
\hline
\end{tabular}

Dari inovasi yang dilakukan oleh pihak pondok pesantren Jam'iyyah Islamiyyah diatas maka dapat dilakukan perhitungan peningkatan inovasi yaitu sebagai berikut:

Tabel. 13

Hasil Perhitungan Inovasi

\begin{tabular}{|c|c|}
\hline & 2017 \\
\hline Inovasi yang terealisasi dalam 3 periode & 4 \\
\hline Inovasi yang ditargetkan & 5 \\
\hline Prosentasi & $80 \%$ \\
\hline
\end{tabular}

Perhitungan diatas menunjukkan bahwa inovasi yang dilakukan pondok Pesantren Jam'iyyah Islamiyyah dapat dikatakan sangat baik yaitu sebesar $80 \%$ dari inovasi yang ditargetkan telah terealisasi. Hal ini dapat diartikan bahwa yayasan telah mampu mengetahui keinginan pelanggan dan identifikasi produk atau jasa untuk memenuhi kebutuhan pelanggan. 
Inovasi yang dilakukan diharapkan dapat memberikan nilai tambah bagi Pondok Pesantren Jam'iyyah Islamiyyah.

2. Proses Pelayanan

Proses pelayanan yang dilakukan dengan menyediakan sarana dan prasarana yang dibutuhkan pelanggan, pengaduan keluhan pelanggan dapat disampaikan secara langsung kepada pihak yayasan baik berupa tertulis maupun tidak tertulis, dan penanganan keluhan pelanggan terhadap layanan dilakukan pihak yayasan secara cepat dan efektif.

Tabel. 13

Pencapaian Sasaran Strategi Perspektif Proses Bisnis Internal

\begin{tabular}{|l|l|l|c|c|c|c|}
\hline \multicolumn{6}{|c|}{ Perspektif Proses Bisnis Internal (Bobot 20\%) } \\
\hline No & Sasaran Strategi & \multicolumn{1}{|c|}{ Ukuran Hasil } & Bobot & Target & Realisasi & Skor \\
\hline 1 & $\begin{array}{l}\text { Peningkatan } \\
\text { inovasi }\end{array}$ & $\begin{array}{l}\text { Pengembangan } \\
\text { inovasi layanan } \\
\text { produk dan jasa } \\
\text { lembaga }\end{array}$ & $10 \%$ & $85 \%$ & $80 \%$ & 9 \\
\hline 2 & $\begin{array}{l}\text { Peningkatan } \\
\text { proses } \\
\text { pelayanan }\end{array}$ & $\begin{array}{l}\text { Meningkatkan } \\
\text { layanan kepada } \\
\text { pelanggan }\end{array}$ & $10 \%$ & $90 \%$ & $90 \%$ & 10 \\
\hline
\end{tabular}

\section{d) Perspektif Pembelajaran dan Pertumbuhan}

Perspektif yang terakhir adalah perspektif pembelajaran dan pertumbuhan. Pengukuran terhadap kinerja dalam perspektif pembelajaran dan pertumbuhan dapat dilakukan dengan melihat beberapa indikator yang meliputi: peningkatan kualitas dan kompetensi (mutu SDM) dan peningkatan kepuasan karyawan.

1. Peningkatan kualitas dan Kompetensi (Mutu SDM)

Untuk mengukur seberapa besar yayasan dalam memberikan peningkatan kualitas dan kompetensi (Mutu SDM) dapat dilihat dari pendelegasian pegawai dalam setiap pelatihan atau seminar yang diadakan diluar yayasan. Dari hasil penelitian didapatkan data bahwa selama periode 2017 yayasan telah mengikut sertakan sebanyak 120 pegawai dari setiap unit dari tingkat RA sampai perguruan tinggi dalam kegiatan pendidikan maupun pelatihan. Dari data tersebut 26 diantaranya yang mewakili pegawai dari unit pondok pesantren sehingga dapat dihitung prosentase pengikut sertaan pegawai dalam meningkatkan kualitas SDM yaitu dengan cara:

$$
\begin{aligned}
\text { Rumus } & =\frac{\text { Jumlah Pegawai yang mengikuti pelatihan }}{\text { Total Pegawai }} \times 100 \% \\
& =\frac{26}{34} \times 100 \% \\
& =76 \%
\end{aligned}
$$

Dari hasil perhitungan diatas dapat dilihat bahwa peningkatan kualitas dan kompetensi pegawai sudah dapat dikategorikan sangat bagus karena telah mencapai $76 \%$.

\section{Peningkatan Kepuasan Pegawai}

Untuk mengukur tingkat kepuasan pegawai dilakukan dengan penyebaran kuesioner. Data dari kuisioner tersebut bersifat kualitatif dan kemudian diubah menjadi kuantitatif dengan memberikan skor pada masing-masing pilihan jawaban. Jumlah kuisioner yang 
dibagikan kepada pelanggan adalah sebanyak 10 kuisioner dengan total pertanyaan dalam kuesioner adalah sebanyak 8 pertanyaan.

Dari 10 kuisioner yang terdiri dari 8 pertanyaan yang dianggap valid. Dari data tersebut dapat ditentukan interval kepuasan untuk mengetahui tingkat kepuasan pegawai. Berikut standar minimal yang ditetapkan untuk melihat tingkat kepuasan pegawai adalah didasarkan pada skala yang digunakan untuk pengolahan data berikut:

$$
\begin{array}{ll}
\text { Interval } & =(\mathrm{IK} \text { maks-IK min }): 5 \\
\text { Ik maks } & =\mathrm{R} \times \mathrm{PP} \times \mathrm{EX} \text { maks } \\
& =10 \times 8 \times 5 \\
& =400 \\
\text { IK min } & =\mathrm{R} \times \mathrm{PP} \times \mathrm{EX} \text { min } \\
& =10 \times 8 \times 1 \\
& =80 \\
\text { Interval } & =(400-80): 5 \\
& =64
\end{array}
$$

Dimana :

$$
\begin{array}{ll}
\mathrm{PP} & =\text { banyak pertanyaan } \\
\mathrm{R} & =\text { jumlah responden } \\
\mathrm{EX} \mathrm{maks} & =\text { skor maksimal yang diberikan } \\
\mathrm{EX} \mathrm{min} & =\text { skor minimal yang diberikan } \\
1.80-144= & \text { dikategorikan sangat tidak puas } \\
\text { 2. } 145-209= & \text { dikategorikan tidak puas } \\
\text { 3. } 210-274= & \text { dikategorikan netral } \\
\text { 4. } 275-339= & \text { dikategorikan puas } \\
\text { 5. } 340-404= & \text { dikategorikan sangat puas }
\end{array}
$$

\begin{tabular}{|c|c|c|c|c|c|c|c|c|c|c|}
\hline \multirow{3}{*}{$\begin{array}{c}\text { Item } \\
\text { pertanyaan }\end{array}$} & \multicolumn{10}{|c|}{ JAWABAN } \\
\hline & \multicolumn{2}{|c|}{ STP } & \multicolumn{2}{|c|}{ TP } & \multicolumn{2}{|c|}{$\mathrm{N}$} & \multicolumn{2}{|c|}{$\mathrm{P}$} & \multicolumn{2}{|c|}{ SP } \\
\hline & $\mathrm{F}$ & $\%$ & $\mathrm{~F}$ & $\%$ & $\mathrm{~F}$ & $\%$ & $\mathrm{~F}$ & $\%$ & $\mathrm{~F}$ & $\%$ \\
\hline 1 & 0 & 0 & 0 & 0 & 2 & 20 & 8 & 80 & 0 & 0 \\
\hline 2 & 0 & 0 & 0 & 0 & 1 & 10 & 7 & 70 & 2 & 20 \\
\hline 3 & 0 & 0 & 0 & 0 & 4 & 40 & 5 & 50 & 1 & 10 \\
\hline 4 & 0 & 0 & 0 & 0 & 2 & 20 & 7 & 70 & 1 & 10 \\
\hline 5 & 0 & 0 & 0 & 0 & 3 & 30 & 5 & 50 & 2 & 20 \\
\hline 6 & 0 & 0 & 0 & 0 & 1 & 10 & 6 & 60 & 3 & 30 \\
\hline
\end{tabular}

Berdasarkan interval data yang dipaparkan, maka lima kategori diatas telah diperoleh. Berdasarkan kategori diatas nanti akan digunakan sebagai perhitungan atas kuisioner dan akan diketahui berada pada posisi manakah tingkat kepuasan karyawan tersebut. Indeks kepuasan karyawan yang diperoleh adalah 311, sehingga dapat dikategorikan pegawai tersebut puas. Hal ini menunjukkan bahwa yayasan sudah mampu mencapai indeks kepuasan yang baik yaitu dengan pegawai merasa puas atau berada pada interval antara 275-339. Berikut disajikan hasil perhitungan kuisioner atas tanggapan responden pada kepuasan pelanggan yaitu sebagai berikut:

Tabel. 14

Jawaban Responden Pelanggan 


\begin{tabular}{|c|c|c|c|c|c|c|c|c|c|c|}
\hline 7 & 0 & 0 & 0 & 0 & 4 & 40 & 6 & 60 & 0 & 0 \\
\hline 8 & 0 & 0 & 0 & 0 & 2 & 20 & 7 & 70 & 1 & 10 \\
\hline
\end{tabular}

Dari tabel diatas dapat dijelaskan bahwa :

a. Sebanyak $80 \%$ responden menyatakan puas dengan pola kebijakan.

b. Sebanyak $70 \%$ responden menyatakan puas dengan kompensasi.

c. Sebanyak $50 \%$ responden menyatakan puas dengan suasana disekitar tempat kerja.

d. Sebanyak $70 \%$ responden menyatakan puas dengan fasilitas, sarana dan prasarana yang disediakan.

3. Sebanyak 50\% responden menyatakan puas dengan hubungan antara atasan dengan bawahan.

4. Sebanyak $60 \%$ responden menyatakan puas dengan bimbingan teknis yang diberikan atasan kepada bawahan.

5. Sebanyak $60 \%$ responden menyatakan puas dengan hubungan antara rekan kerja.

6. Sebanyak $70 \%$ responden menyatakan puas dengan kesempatan alih tugas.

Tabel 4.23

Pencapaian Sasaran Strategi Perspektif Pembelajaran dan pertumbuhan

\begin{tabular}{|c|l|l|c|c|c|c|}
\hline \multicolumn{7}{|c|}{ Perspektif Pembelajaran dan pertumbuhan (bobot 20\%) } \\
\hline No & Sasaran Strategi & \multicolumn{1}{|c|}{ Ukuran Hasil } & Bobot & Target & Realisasi & skor \\
\hline \multirow{2}{*}{1} & $\begin{array}{l}\text { Peningkatan } \\
\text { kualitas dan } \\
\text { Kompetensi } \\
\text { (Mutu SDM) }\end{array}$ & $\begin{array}{l}\text { Prosentase } \\
\text { keikutsertaan } \\
\text { pegawai dalam } \\
\text { pelatihan dan } \\
\text { seminar }\end{array}$ & $10 \%$ & $80 \%$ & $76 \%$ & 9 \\
\hline 2 & $\begin{array}{l}\text { Peningkatan } \\
\text { kepuasan pegawai }\end{array}$ & $\begin{array}{l}\text { Peningkatan } \\
\text { kepuasan kerja } \\
\text { pegawai }\end{array}$ & $10 \%$ & $100 \%$ & $90 \%$ & 9 \\
\hline
\end{tabular}

Berdasarkan dari uraian tabel yang menjelaskan tentang pencapaian strategi dari masing-masing perspektif Balanced Scorecard yaitu perspektif keuangan, perspektif pelanggan, perspektif proses bisnis internal dan perspektif pembelajaran dan pertumbuhan dapat disimpulkan dalam sebuah tabel matriks Balanced Scorecard. Berikut ini adalah hasil matriks Balanced Scorecard dari masing-masing perspektif yaitu:

Tabel. 15

Matriks Balanced Scorecard Untuk Pondok Pesantren Jam'iyyah Islamiyyah

\begin{tabular}{|c|l|l|c|c|c|c|}
\hline Perspektif & $\begin{array}{l}\text { Sasaran } \\
\text { Strategi }\end{array}$ & Ukuran & Bobot & $\begin{array}{c}\text { Targe } \\
\mathbf{t}\end{array}$ & $\begin{array}{c}\text { Realisas } \\
\mathbf{i}\end{array}$ & $\begin{array}{c}\text { Sko } \\
\mathbf{r}\end{array}$ \\
\hline \multirow{2}{*}{ Keuangan } & $\begin{array}{l}\text { Efisiensi } \\
\text { aktivitas non } \\
\text { program }\end{array}$ & $\begin{array}{l}\text { Efisiensi } \\
\text { aktivitas non } \\
\text { program }\end{array}$ & $7 \%$ & $75 \%$ & $50 \%$ & 5 \\
\cline { 2 - 7 } & $\begin{array}{l}\text { Dukungan } \\
\text { publik }\end{array}$ & $\begin{array}{l}\text { Peningkatan } \\
\text { pendapatan } \\
\text { dari publik }\end{array}$ & $6 \%$ & $75 \%$ & $75 \%$ & 6 \\
\hline
\end{tabular}




\begin{tabular}{|c|c|c|c|c|c|c|}
\hline & $\begin{array}{l}\text { Efisiensi } \\
\text { program }\end{array}$ & $\begin{array}{l}\text { Efisiensi } \\
\text { program }\end{array}$ & $7 \%$ & $75 \%$ & $60 \%$ & 6 \\
\hline \multirow{2}{*}{ Pelanggan } & $\begin{array}{l}\text { Peningkatan } \\
\text { jumlah } \\
\text { pelanggan }\end{array}$ & $\begin{array}{l}\text { Meningkatkan } \\
\text { jumlah } \\
\text { pelanggan }\end{array}$ & $10 \%$ & $75 \%$ & $47 \%$ & 6 \\
\hline & $\begin{array}{l}\text { Peningkatan } \\
\text { kepuasan } \\
\text { pelanggan }\end{array}$ & $\begin{array}{l}\text { Peningkatan } \\
\text { indeks } \\
\text { kepuasan } \\
\text { pelanggan }\end{array}$ & $30 \%$ & $100 \%$ & $95 \%$ & 28 \\
\hline \multirow{2}{*}{$\begin{array}{l}\text { Proses Bisnis } \\
\text { Internal }\end{array}$} & $\begin{array}{l}\text { Peningkatan } \\
\text { inovasi }\end{array}$ & $\begin{array}{l}\text { Pengembanga } \\
\mathrm{n} \text { inovasi } \\
\text { layanan } \\
\text { produk dan } \\
\text { jasa lembaga }\end{array}$ & $10 \%$ & $85 \%$ & $80 \%$ & 9 \\
\hline & $\begin{array}{l}\text { Peningkatan } \\
\text { proses } \\
\text { pelayanan }\end{array}$ & $\begin{array}{l}\text { Meningkatkan } \\
\text { layanan } \\
\text { kepada } \\
\text { pelanggan }\end{array}$ & $10 \%$ & $90 \%$ & $90 \%$ & 10 \\
\hline \multirow[t]{2}{*}{$\begin{array}{l}\text { Pembelajaran } \\
\text { dan } \\
\text { pertumbuhan }\end{array}$} & $\begin{array}{l}\text { Peningkatan } \\
\text { kualitas dan } \\
\text { Kompetensi } \\
\text { (Mutu SDM) }\end{array}$ & $\begin{array}{l}\text { Prosentase } \\
\text { keikutsertaan } \\
\text { pegawai } \\
\text { dalam } \\
\text { pelatihan dan } \\
\text { seminar }\end{array}$ & $10 \%$ & $80 \%$ & $76 \%$ & 9 \\
\hline & $\begin{array}{l}\text { Peningkatan } \\
\text { kepuasan } \\
\text { pegawai }\end{array}$ & $\begin{array}{l}\text { Peningkatan } \\
\text { kepuasan } \\
\text { kerja pegawai }\end{array}$ & $10 \%$ & $100 \%$ & $90 \%$ & 9 \\
\hline \multicolumn{6}{|c|}{ Total Skor } & 88 \\
\hline
\end{tabular}

Tabel di atas memperlihatkan bahwa skor keseluruhan yang diperoleh yaitu sebesar 88 dan dikategorikan baik. Dari matriks Balanced Scorecard tersebut dapat dilihat sasaran strategi mana yang belum mencapai target yang telah ditetapkan sehingga untuk ke depannya dapat dievaluasi dan diperbaiki lagi kinerjanya.

Berikut ini adalah dashboard balanced scorecard untuk mengetahui kriteria penilaian yang telah dicapai oleh pondok pesantren yaitu:

Tabel 4.25

Kriteria Penilaian Kinerja

\begin{tabular}{|c|c|c|}
\hline Rentang nilai & Kriteria & Warna \\
\hline $93-100$ & Sangat Baik & Hijau Tua \\
\hline $83-92$ & Baik & Hijau Muda \\
\hline $70-82$ & Cukup & Kuning \\
\hline $50-69$ & Kurang & Merah Muda \\
\hline Dibawah 50 & Sangat Kurang & Merah Tua \\
\hline
\end{tabular}


Berikut juga disajikan gambar dashboard balanced scorecard untuk penilaian kinerja yayasan yaitu:

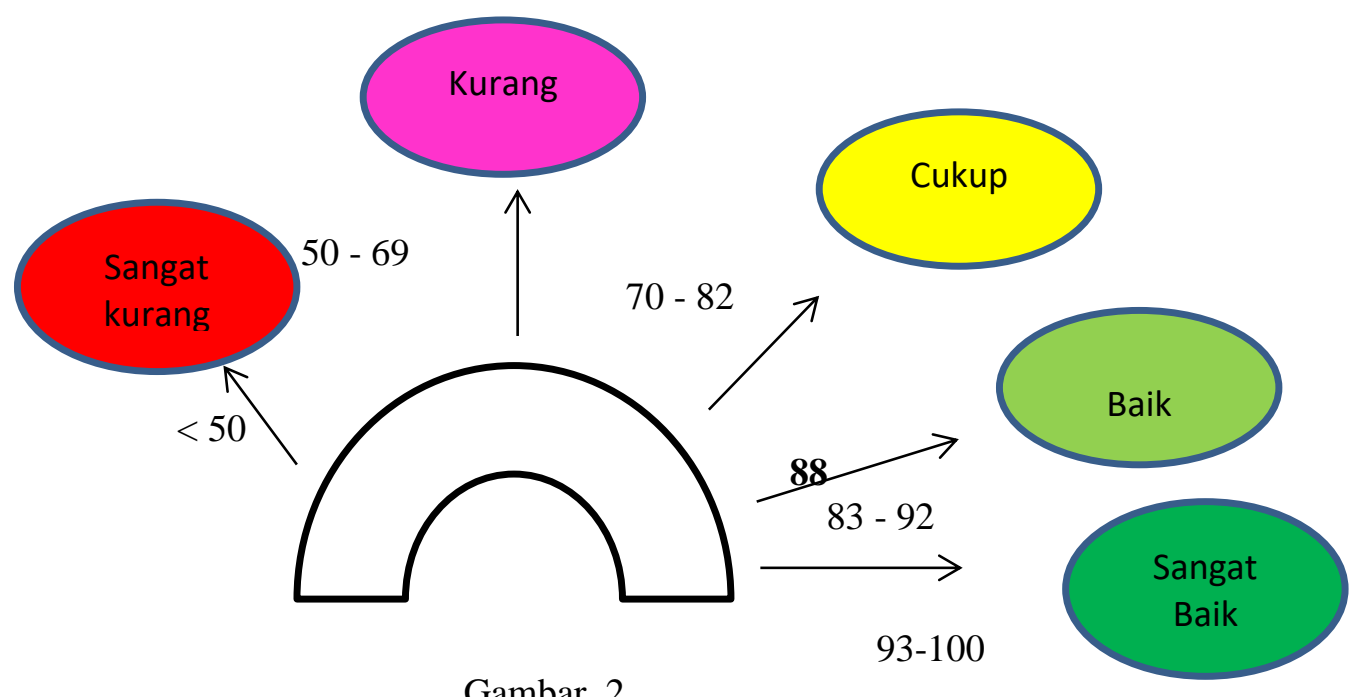

Dashboard Balanced Scorecard

Dashboard balance scorecard menjelaskan bahwa matrik pengukuran kinerja Pondok Pesantren Jam'iyyah Islamiyyah memperoleh skor secara keseluruhan sebesar $88 \%$. Menurut kriteria penilaian kinerja bahwa Pondok Pesantren Jam'iyyah Islamiyyah masuk dalam kategori area hijau muda yang memiliki rentang nilai di atas 86-100. Hal ini menunjukkan bahwa kinerja pondok Pesantren Jam'iyyah Islamiyyah dari keempat perspektif balanced scorecard dikategorikan baik. Pada perspektif keuangan dalam segi keuangan maupun non keuangan secara garis besar sudah memiliki kinerja yang sangat baik, namun ada beberapa hal yang masih harus dievaluasi dan diperbaiki ke depannya dari masing-masing perspektif. Hal dapat dilihat bahwa pada perhitungan rasio efisiensi aktivitas non program dan rasio efisiensi aktivitas program masing-masing memperoleh realisasi sebesar $50 \%$ dan $60 \%$ sedangkan target yang ditentukan adalah sebesar $75 \%$, hal ini menggambarkan bahwa pada kinerja perspektif ini masih perlu dilakukan evaluasi lagi agar ke depannya bisa lebih baik.

Pada perspektif pelanggan bahwa khususnya pada akuisisi pelanggan memerlukan sedikit evaluasi karena pencapaian realisasi sebesar $47 \%$ sedangkan target yang diinginkan pondok Pesantren adalah sebesar $75 \%$, hal ini menggambarkan bahwa masih kurangnya pencapaian kinerja dalam perspektif ini. Pada perspektif proses bisnis internal sudah cukup bagus hanya saja pada peningkatan inovasi perlu sedikit dievaluasi karena realisasinya sebesar $80 \%$ dan belum mencapai target yang diinginkan yaitu $85 \%$ sehingga inovasi yang dilakukan oleh Pondok Pesantren perlu ditambah dan ditingkatkan kembali. Pada perspektif pembelajaran dan pertumbuhan yang perlu ditingkatkan dan diperhatikan adalah kepuasan pegawai. Pada perspektif ini realisasi adalah sebesar $90 \%$ dan target yang diinginkan adalah $100 \%$ sehingga perlu sedikit perbaikan agar bisa mencapai target yang ditentukan.

\section{Kesimpulan}

Hasil dari keempat perspektif balanced scorecard dikategorikan baik dengan jumlah perolehan yaitu $88 \%$ dengan rincian sebagai berikut:

Pertama, Perspektif Keuangan (Finance). Perspektif ini menunjukkan bahwa pendapatan yang diperoleh Pondok Pesantren mengalami penurunan ditahun berikutnya sehingga pada tahun 2017 mengalami penurunan sebesar 0,49 dari tahun sebelumnya. Sedang pada rasio dukungan publik menunjukkan bahwa dari tahun ketahun mengalami peningkatan. Pada tahun 2017 rasio ini mengalami peningkatan sebesar 5\% dari tahun sebelumnya. Hal ini menunjukkan bahwa kontribusi yang diperoleh dari donatur dapat diperoleh dengan baik. 20 | Mumtäz Vol. 3 No. 1, Tahun 2019 
Dilihat dari rasio efisiensi program, rasio ini mengalami fluktuasi tiap tahunnya dan pada tahun 2017 rasio ini mengalami penurunan sebesar 10\% dari tahun sebelumnya. Hal ini menunjukkan bahwa biaya program yang dikeluarkan yayasan mengalami penurunan;

Kedua, Perspektif Pelanggan (Customer). Hasil yang diperoleh menunjukkan bahwa kinerja yayasan sudah cukup baik karena mampu memenuhi target baik dari proses akuisisi pelanggan maupun peningkatan kepuasan pelanggan. Pada akuisisi pelanggan terlihat bahwa jumlah santri mengalami peningkatan dari tahun ke tahun, kemudian pada peningkatan kepuasan pelanggan memperoleh indeks kepuasan pelanggan sebesar 4.898 dan dikategorikan puas

Ketiga, Perspektif proses bisnis internal. Pada perspektif ini dapat dilihat bahwa kinerja pada perspektif ini sudah dapat dikatakan sangat baik, dari peningkatan inovasi pondok pesantren mampu merealisasikan dengan angka yang mendekati target yang diinginkan yaitu sebesar $80 \%$ dari target $85 \%$ sehingga sudah baik dalam kinerjanya. Pada peningkatan proses pelayan kepada pelanggan sudah sangat baik kinerjanya hal ini terlihat dari pencapaian realisasi sebesar $90 \%$ yang telah mencapai target yaitu $90 \%$.

Keempat, Perspektif pembelajaran dan pertumbuhan. Kinerja pada perspektif ini sudah sangat baik dikarenakan telah mampu mencapai indikator yang diinginkan yaitu pada peningkatan kualitas dan kompetensi (mutu SDM) telah mampu merealisasikan sebesar $91 \%$ dari target $75 \%$ sehingga dalam hal ini kinerjanya sudah sangat baik. Dan yang terakhir pada peningkatan kepuasan pelanggan telah mampu mendekati target yang diinginkan yaitu sebesar 90\% dari target $100 \%$ sehingga kinerjanya dikatakan sangat baik.

Manajemen Pondok Pesantren Jam'iyyah Islamiyyah bisa dikatakan efektif sesuai dengan indikator berupa: a) Jumlah hasil yang dapat dikeluarkan; b) Tingkat kepuasan yang diperoleh; c) Produk kreatif; d) Intensitas yang akan dicapai. 


\section{DAFTAR PUSTAKA}

Dally, Dadang. Balanced ScoreCard:Suatu Pendekatan Dalam Implementasi Manajemen Berbasis Sekolah. Bandung: PT Remaja Rosdakarya., 2010.

Danim, Sudarwan. 2012. Motivasi Kepemimpinan Dan Efektivitas Kelompok. Jakarta: Rineka Cipta, 2012.

Dhofier, Zamakhsyari. Tradisi Pesantren: Studi Tentang Pandangan Kyai. Jakarta: LP3ES. Cet. VII. Jakarta: LP3ES, 2011.

Fahmi, Irham. Manajemen Kepemimpinan: Teori Dan Aplikasi. Bandung: ALPABETA, 2014.

Hayati, Nur Rohmah. "Manajemen Pesantren Dalam Menghadapi Dunia Global. Tarbawi, 1(2), 97-106." Tarbawi 1, no. 2 (2015): 97-106.

Jamali. Kaum Santri Dan Tantangan Kontemporer. Bandung: Pustaka, 1999.

Krismiaji. Sistem Informasi Akuntansi. Yogyakarta: AMP YKPN, 2002.

Mahmudi. Manajemen Kinerja Sektor Publik. Yogyakarta: STIE YKPN, 2010.

Mulyadi. Balanced Scorecard: Alat Manajemen Kontemporer Untuk Pelipatganda Kinerja Keuangan. Jakarta: Salemba Empat, 2001.

Nasir, Nanat Fatah. Integrasi Dan Konflik Dalam Adat Pertanian Masyarakat Aceh. I. Bandung: Gunung Djati Press, 1999.

Nurkholis. Manajemen Berbasis Sekolah, Teori, Model, Dan Aplikasi. Jakarta: PT. Gramedia Widiasarana Indonesi, 2003.

O.H.Chang dan C.W, Chow. "The Balanced Scorecard: A Potential Tool for Supporting Change and Continuous Improvement in Accounting Corporation." Meditari Accountancy Research 14, no. 3 (1999): 395-412.

Rangkuti, Freddy. SWOT Balance Scorecard. Jakarta: Gramedia Pustaka Utama, 2012.

Robert S. Kaplan, and David P. Norton. The Balanced Scorecard: Translating Strategy into Action. Boston: Harvard Business School Press, 1996.

Sugiyono. Metode Penelitian Pendidikan: Pendekatan Kuantitatif, Kualitatif, Dan R \& D. 11th ed. Bandung: ALPABETA, 2010.

Sukmadinata, Nana Syaodih. Metode Penelitian Pendidikan. Bandung: PT. Rosdakarya, 2007.

Yakin, Nurul. "2014. Studi Kasus Pola Manajemen Pondok Pesantren Al-Raisiyah Di Kota Mataram.” Ulumuna Jurnal Studi Keislaman 18, no. 1 (2014): 201. 